\title{
The Humanistic Approach to Upbringing and Education in the Creative Legacy of the Ukrainian Pedagogues of the Second Half of the 19th Century
}

\author{
Ivan Pavlovych Anosov ${ }^{1}$, Mark Veniaminovych Elkin ${ }^{1}$, Marina Mykhaylivna Golovkova ${ }^{1}$, Angelina Anatoliivna \\ Korobchenko ${ }^{1} \&$ Mykola Mykolayovych Oksa ${ }^{1}$ \\ ${ }^{1}$ Melitopol Bogdan Khmelnitskiy Pedagogical University, Ukraine \\ Correspondence: Angelina Anatoliivna Korobchenko, Melitopol Bogdan Khmelnitskiy Pedagogical University, \\ Ukraine.
}

Received: November 14, 2014

Accepted: January 5, 2015 Online Published: May 28, 2015

doi:10.5539/ies.v8n6p 171

URL: http://dx.doi.org/10.5539/ies.v8n6p171

\begin{abstract}
The article is dedicated to the study of the humanistic approach to upbringing and education in the creative legacy of the Ukrainian pedagogues of the second half of the $19^{\text {th }}$ century. Through the analysis of S. Myropolskiy's and Kh. Alchevska's pedagogical legacy, a world outlook position of scholars concerning humanisation of the educational process is shown. In the course of the research, it is found out that basis of S. Myropolskiy's and Kh. Alchevska's conception was formed by the principles, confirmed by humanistic pedagogy. They revealed the humane approach essence to realizing the educational process in the national school. It is established that the pedagogues considered the teacher's personality as an important figure of the human upbringing process.
\end{abstract}

Keywords: humanism, humanization, educational process, teacher, educational institution, education, upbringing

\section{Introduction}

Sociocultural changes, taking place in Ukraine, influenced the development and modernization of education. Having the conditions of the integration and global character of educational processes, the problem of the educational process humanization is being actualized. One of the directions, enabling to solve this problem, is a fundamental study, an objective appreciation, a creative comprehension and employment of the best traditions of Ukrainian education and pedagogy with the purpose of optimal combining of the past and the modern achievements of the scientific thought. In this context, the investigation of the educational and pedagogical activity experience of S. Myropolskiy and Kh. Alchevska, little-known representatives of the second half of the $19^{\text {th }}$ century, roses special interest.

The second half of the $19^{\text {th }}$ century in the Russian empire, and Ukraine being its constituent part, was characterized by considerable transformation in social, economic and political life. This period is also characterized by the development of theoretical pedagogy, the creation of pedagogical literature and journalism, various pedagogical tendencies and parties. A new pedagogic standard, foreseeing the common human development of the rising generation and bringing the child's personality to the foreground in the course of education and upbringing was propounded.

\section{Methods}

For obtaining objective information in the studied problem, the following research methods were used: chronological-for analyzing S. Myropolskiy's and Kh. Alchevska's pedagogic views in the context of the historic epoch; concrete-and-searching-for searching and analyzing the published materials, historical and pedagogical references and modern investigation materials; historical-and-structural-with the purpose of determining the trends of theoretical and practical teaching activity of the pedagogues; retrospective-and-historical-for analyzing didactic and methodological works written by S. Myropolskiy and Kh. Alchevska: a systematization and generalization method-for determining, comparing and correlating the opinions of S. Myropolskiy and Kh. Alchevska; a method of interpretation and generalization of the worked up materials-for formulating conclusions. 


\section{Results and Discussions}

The analysis of the published works by pedagogues and specialists in educational methods, their reports at the teachers' congresses and conferences, the statements of practicing teachers on the pages of newspapers and journals makes it possible to assert that just since the second half of the $19^{\text {th }}$ century, the didactics of our country had been developing as a theory of the training and developing instruction, a goal-directed elaboration of the theoretical ground of humanism principles and their realization had been carrying out.

The idea of education and upbringing humanization was supported by the progressive pedagogic circles and became a certain theoretical conception. Among those, who worked out this conception, were scholars, pedagogues, writers and public figures-Khrystyna Alchevska, Heorhii Vaschenko, Borys Hrinchenko, Mykhailo Drahomanov, Oleksandr Dukhnovych, Mykola Korf, Panteleimon Kulish, Mukhailo Maksymovych, Sergii Myropolskiy, Mykola Pyrohov, Sofiia Rusova, Lesia Ukrainka, Ivan Franko, Kostiantyn Ushynskyi, Taras Shevchenko and others. Because of the world view peculiarity, the pedagogical legacy of many scholars had not been studied in detail by the Soviet totalitarian system for a long time (Humanization of the educational process in elementary school, 2001).

The pedagogical legacy of such little studied enlightener teachers and practicing teachers of the researched period as S. Myropolskiy and Kh. Alchevska is of great significance for a further development of the Ukrainian pedagogical theory and practice (Encyclopaedia of education, 2008). In our investigation we found out, that the foundations of S. Myropolskiy's and Kh. Alchevska's humanistic conception were the principles, confirmed by humanistic pedagogy: the principle of respect for the personality of a child and a teacher as the main characters of the pedagogic process; the consideration of individual and age special features of pupils as well as their abilities; the individualization of the instruction process; the respect for the man's right to make his life and career choice by himself.

In our opinion, S. Myropolskiy's little known theoretical ideas and his practical and methodological activity experience are interesting. S. Myropolskiy's views on upbringing are reflected in numerous scientific and methodological articles-"What is our task?" (1873), "Life and school. Practical tasks of the national school" (1874), "What should our national school be?" (1876), "The modern state of the issue on compulsoriness of primary education in Russia" (1876) and in the books-"The national school according to Komensky's ideas" (1873), "Dydactic essays" (1890) and others. S. Myropolskiy, like his compatriots Kh. Alchevska, N. Bunakov, V. Vodovozov, M. Drahomanov, M. Korf, M. Pyrohov, V. Stoiunin, K. Ushynskyi, saw a power of all reforms, the improvement of public and economic life and a basis of social changes in national upbringing. S. Myropolskiy took a very serious approach in theoretical motivation of the personality upbringing problems. In his opinion, both fundamental knowledge of pedagogical theories of the past and a critical attitude to them are important and useful for modern times. His teaching experience and theoretical knowledge enabled him to prove the importance of upbringing that must start from childhood (Miropolskiy, 1872).

In his work "Didactic essays, a pupil and upbringing instruction" (1890), the pedagogue revealed his interpretation of the nation of "upbringing" as a goal-oriented and natural process of man's development. From the pedagogue's point of view, "to deprive a child of upbringing means to leave him to the mercy of fate, and to give him stupid upbringing means to humiliate him" (Miropolskiy, 1890, pp. 2-3). S. Myropolskiy considered a pupil the object of upbringing and a teacher-the instrument of upbringing influence, responsible for his successful future. "For a teacher, a child is a book, written in an incomprehensible language, but it must be read without fail" (Miropolskiy, 1890, pp. 2-3).

The humanistic value orientation of pedagogic views, usual for S. Myropolskiy, has made it possible to assert that the main aims of upbringing are the formation of man as personality; the harmonic development of all the abilities and gift of children; the creation of conditions for the all-round development and self-development of a pupil as personality; the cultivation of his feeling of self-respect and self-esteems; the formation of his moral convictions, will, feeling of civic responsibility and realizing the necessity of self-upbringing.

The analysis of the pedagogue's teaching legacy enabled us to formulate the task of the national school, emphasized by him: to provide the all-round harmonic development of personality; to put the upbringing influence on a child into practice for "the formation of human character"; to rouse his desire to self-education. Besides, he considered instruction and upbringing in a tight interconnection. In his work "The national school according to Komensky's ideas", S. Myropolskiy stressed, that the entire school course should develop man and make him generous (Miropolskiy, 1873).

Myropolskiy's humanism consists in understanding the high mission of a child. In his work "Didactic essays", he revealed the essence of the human approach to realizing the tasks of the instruction and upbringing process in the 
national school: love and respect for a child; a child's right to education; parents' and teachers' love; teachers' and parents' optimism; a deep faith in the child's power and opportunities; the organization of correct upbringing for discovering the strength energy, abilities and positive features of a child; the creation of conditions for the all-round development and studies of a child; the creation of methodologies which will "easily" enable to realize the process of instruction; a thorough choice of upbringing methods; the creation of the atmosphere of psychological comfort in the process of instruction; the availability of a teacher's pedagogical tact; teachers' mutual understanding among themselves and pupils; writing manuals and textbooks which corresponds to "childish nature"; a teacher's general and special training for his work in the humane upbringing school" (Miropolskiy, 1890, pp. 58-68). The pedagogue believed that "humane upbringing", like the whole life, should be a deliberate and purposeful activity, foresee a distant and concrete goal of the upbringing process, taking its laws and principles into account.

The analysis of S. Myropolskiy's main works testifies to direct using in the instruction and upbringing process such principles as "nature harmony", "humanity", "national character", "individualization" and "a lively connection between a family and a school". The pedagogue thought that the school for people should be "a workshop of humanity" (Miropolskiy, 1871, pp. 9-10). The scholar was sure that the national school, constructed on humanity, will promote developing a child's "mentality, will, heartiness, individuality, a feeling of self-respect, responsibility" and become available for everybody. The pedagogue saw the realization of correct upbringing of a child in the "support on the positive features" in his disposition.

Myropolskiy considered a reasonable insistence on a high standard to a child on a teacher's part as one of the most important conditions of humane upbringing. He, like his compatriots, called upon teachers to treat a child as personality with love and respect. He wrote: "Love a child and teach him ... You have ... "man" before you, remember it and respect him" (Miropolskiy, 1882, p. 46). He recommended teachers to develop and encourage such common human features of a child as soul sympathy, truthfulness, modesty, diligence and a feeling of duty.

Thus, Myropolskiy carried out an integrated system of upbringing theory, whose cardinal components are the purpose, tasks, principles, contents, methods and conditions. His views on the process of upbringing humanisation at school were of positive character for the second half of the 19th century, they reflected a humane and democratic approach to the process of personality's all-round upbringing. His words "Children's future depends on upbringing ... The welfare of our nation and family as well as public morality depend upon the fact how a future citizen of our state will be brought up" have not lost their topicality (Miropolskiy, 1890, p. 12).

The typical feature for the humanistic views of country's pedagogues was the fact that they considered a teacher's personality as an important figure of the humane upbringing process, in which the conditions for manifesting individuality, mastery and self-realization, improving professionalism and creative work, conforming moral prestige of a teacher's personality in society and at school, respecting for a teacher and a teaching staff on the part of pupils, parents and the public and a corresponding appreciation of teaching should be created. In their theoretical works and methodological recommendations, they revealed the teacher's role in the educational process, formulated demands upon him as an educator and organizer of the educational process, worked out a system of training a teacher and even tried to put all this into practice in their practical activity. The fact that school and a teacher are responsible for children's moral upbringing and for their many-sided development was accepted by most intellectuals as an axiom in the $19^{\text {th }}$ century. Those pedagogues thought that the teachers characterized by the humanity, expressing in the respect, strictness and love for pupils, in the wish and ability to listen to them and to teach them, in stimulating independence, initiative, activity and creation, should work at school.

The analysis of Kh. Alchevska's pedagogical legacy, archive records, scientific and pedagogical materials made it possible to reveal the specific character of humanistic purposefulness of the scholar's pedagogic views on training a teacher and demands upon him. Like S. Myropolskiy, Kh. Alchevska highly appraised the role of teacher's individual features in the process of instruction and upbringing a child, she underlined that the pedagogical influence success did not lie in the form and means, it consisted in a teacher as personality (Mukhin, 1979). The humane teacher should possess such traits as insistence and love for pupils, the desire and ability to bring up, teach and develop them, to stimulate children's independence, initiative, activity and creation. She paid attention to the fact that a good man can be brought up only by a good man (Abramov, 1900).

In her pedagogical works, Kh. Alchevska directly touched the problem of humanisation of the relations in the systems "teacher-pupil" and "teacher-teacher". In the relations "teacher-pupil", Kh. Alchevska gave a teacher the role of a wise tutor, who supports and directs a pupil in the process of cognition, who teaches to treat himself 
demandingly, who tries to form pupil's firm moral convictions and will for self-education, self-upbringing and self-knowledge (Alchevska, 1912). In Kharkiv Sunday school, whose founder and head mistress was Kh. Alchevska, the relations between the teachers and pupils were warm and friendly. Ya. Abramov wrote that the important distinctive feature of Kh. Alchevska's school was attention to a pupil as a human being (Abramov, 1897). The relations of all the participants of the pedagogic process in this school were based on the mutual respect for one another. Every step of the contacts with the girls was imbued with love for them and attention to their inner world. Just this brought the schoolgirls, Kh. Alchevska and the teacher staff closer.

First of all, the process of instruction and upbringing humanization depends on a teacher and a teaching staff as well as on the relations between them (Marchak, 2006). Mrs. Alchevska gave proof of some important principles of teaching ethics, that have not lost their urgency in the school of today: teachers should appreciate their dignity and take care of its keeping safe; pedagogues and school leaders must create conditions for preserving the professional and moral image of an instructor in schoolchildren's eyes; teachers must be honest and frank in the contacts with their pupils; the relations in a group should be based on confidence, respect and collaboration. Only in this way, Kh. Alchevska asserted, an aim, set in teaching, can be achieved.

From the humanistic attitude, Kh. Alchevska took her approach in creating a teaching collective body. Her traits as a leader should be noted, namely: respect for colleagues' human dignity; drawing all the members of a collective body into activity; an even distribution of the amount of work to be done among teachers; creating the psychological comfort atmosphere in a collective body; the ability to restrain negative emotions and stand above your own likes and dislikes; giving up commanding methods of management and making decisions by taking the needs of a collective body into consideration; motivating the actions by concrete circumstances. The service of S Myropolskiy, and Kh. Alchevska, as the first leaders of Sunday schools in Kharkiv, is the substantiation of the particular role of teaching councils in the educational process, namely in school life humanisation. They came to a conclusion that the basis of their activity must be the principles of collegiality, respectful attitude to every teacher, publicity, the principle of equal chances for all the teachers to express their opinions freely. To the scholars' mind, teaching councils should become special methodological creative laboratories, where all the important issues of school life are discussed.

The humanistic trend of Kh. Alchevska's views was reflected in solving the problem of national character in upbringing. She was convinced of the fact that bringing up a citizen, a devoted patriot should be imbued with the interests of a nation, and this is possible through putting the principle of national character into practice. She thought that the basis of national character should be humanity, kindness, solidarity and humanism. National character is the main condition of personality's moral upbringing. National character is the pedagogic sphere which enables to discern good and evil, which enables to give a correct definition of a humane acts and deeds (Alchevska, 1895).

Keeping up the traditions of her predecessors and contemporaries, she believed in her nation, loved it and respected ancient national traditions. Kh. Alchevska carried out theoretical and sought practical ways of realizing upbringing ideals in Ukrainian school on the basis of the important humanistic principles-love for man and respect for his dignity. For the Ukrainian nation revival, she considered it necessary to restore the traditional ideals of Ukrainians, such moral features as friendly spirit, fraternity, industry, frankness, responsibility and others. Spreading the humanistic approach in bringing up the respectable attitude to other nations, she pointed out a wide employment of the humanistic potential of folk songs, customs, rituals, Ukrainian history, and creative works of outstanding figures of our culture in the upbringing process.

\section{Report}

Humanity has always been the principle description of humanism with all its modifications in the historical development. In the process of the investigation, the specific character of the humanistic direction of S. Myropolskiy's, and Kh. Alchevska's pedagogic views is revealed. It is established that the scholars' humanistic pedagogic views conclude such traditional for humanistic pedagogy principles as a deep love for children and care of a child as personality and individuality. In addition, the main purpose of upbringing is recognizing and discovering natural abilities of a child. They supplemented the conception of "common human education", the conception of humane attitude to a pupil and a teacher as individuals, the humanistic conception of national education.

Preceding from the fact that humanization of the educational process is the most priority direction in reforming the modern Ukrainian school, we consider it reasonable to use our country's positive experience of humanization of the instruction and upbringing process in educational institutions. The ways of realizing the principle of humanism, worked out by S. Myropolskiy and Kh. Alchevska, have not lost their urgency today; they are the 
creation of conditions for the formation of the best human features of a child (honesty, dignity, truthfulness), the revelation of his gifts; the humane treatment and respect for personality, humanization of the relations between an educator and his pupils. They concretized and extended the demands upon a teacher, who takes a leading part in the process of the instruction and upbringing humanization.

However, it should be noted that the carried out research does not claim a complete and exhaustive study of the problem owing to its complexity and diversity. The investigation opens wide prospects and intends to set new urgent tasks which consist in searching alternative effectual conditions of the formation of the growing generation humanistic values.

\section{References}

Abramov, Ya. V. (1897). The private Sunday school in Kharkiv and Sunday schools in general. St. Petersburg.

Abramov, Ya. V. (1900). Our Sunday schools. Their past and present. St. Petersburg.

Alchevska, Kh. D. (1895). Half a year from the Sunday school life: From the Sunday school mistress's notebook. St. Petersburg.

Alchevska, Kh. D. (1912). The meditated and undergone moments: Diaries, letters, memoirs. Moscow.

Encyclopaedia of education. (2008). Academician of Pedagogics (Ukraine). Kiev: Yurinkom Inter.

Humanization of the educational process in elementary school. (2001). Textbook. Under the editorship of S. P. Bondar. Kiev: Stilos.

Marchak, O. O. (2006). Democratization and humanization of activity of the modern secondary school. Principal of school, lyceum, gymnasium, 6, 65-68.

Miropolskiy, S. I. (1871). The idea of upbringing education as applied to national school. Journal of Ministry of Education, 153, 1-25.

Miropolskiy, S. I. (1872). Teacher of the national school. National school, 2, 10-19.

Miropolskiy, S. I. (1873). National school according to the ideas of Comenius. Our national school, 2, 102-146; 4-5, 270-333; 6, 29-101.

Miropolskiy, S. I. (1882). School and society. Kharkov private Sabbath school for women. St. Petersburg Type. I. N. Skorokhodov.

Miropolskiy, S. I. (1890). Didactic essays. Pupil and upbringing education in national school. St. Petersburg; Edition of I. Skorokhodov.

Mukhin, M. I. (1979). Kh. D. Alchevska's pedagogic views and educational activity. Kiev: Higher School.

Pashchenko, D. I. (2001). Genesis of humanistic ideas in pedagogics: Monograph. Kiev: Naykoviy svit.

\section{Copyrights}

Copyright for this article is retained by the author(s), with first publication rights granted to the journal.

This is an open-access article distributed under the terms and conditions of the Creative Commons Attribution license (http://creativecommons.org/licenses/by/3.0/). 